Factors and Social Services, and Community Organization, and each commission formulated a number of recommendations. A plenary session approved motions proposed by the head of the French delegation relating to the continuation of international co-operation in the matter of rural welfare and the holding of other similar conferences.

\title{
World Health Organization: Regional Office for Africa
}

THE report of the Director, published in August 1953, gives a brief account of the organization of the office for Africa in Geneva and its transfer to Brazzaville in October 1952, and describes the work of the year 1952/3. Many initial difficulties had to be overcome-in particular, shortage of housing, high costs of living, and ill health among members of the staff. In addition, though communication with Europe was good, trans-African postal services and other means of communication were slow and unreliable. Recruiting of professional and office staff has also been difficult. The report emphasizes the need for the appointment of an Information Officer, whose duties would be to familiarize himself with what has been done in the field of public health in different territories, to keep the Regional Office informed on events in the field of public health administration, and to be responsible for external information, making known to the African world the policy, aims, and methods of the World Health Organization.

The report makes special mention of the appointment of a cultural anthropologist, M. Jean-Paul Lebeuf (see Africa, xxiii. 2, p. I58), and of the importance of the study of the habits and reactions of human beings by a specially trained social scientist. During the year under review M. Lebeuf attended a meeting of the Scientific Council for Africa South of the Sahata (C.S.A.) at Kampala, and also travelled in the Cameroons and attended the UNESCO International Seminar on Public Libraries in Africa, held at Ibadan, July 1953.

Dr. Carothers, attached to the Regional Office for the purpose of studying psychiatric and psychological problems, visited Belgium, England, France, and the United States and several areas in Africa; he also attended the meeting of the Centre International de l'Enfance in Brazzaville in December 1952.

Dr. J. Karefa-Smart, Public Health Medical Officer, delivered an address on 'The West African Village and its Problems' at the West African Area Conference of the Y.M.C.A. held at Accra in March and April I953.

The report concludes with a warning against attempting to introduce into Africa ' western' systems of public health administration and social programmes without considering whether such systems and programmes are suitable for application in the African environment, and against starting expensive and elaborate schemes which cannot be maintained or cannot at a later date be taken over by the population itself.

\section{UNESCO Seminar on the Development of Public Libraries in Africa}

UNESCO has held four seminars on Public Libraries development of which the last took place at Ibadan, Nigeria, from 27 July to 21 August I953 (see Africa, xxiii. 2, p. 159). The purpose of the seminar was to study the principal public library problems in Africa and to draft proposals for the development of public library services, particularly in connexion with mass education. Twenty-nine librarians and educationists took part, from a great number of African territories as well as Egypt, France, and the United Kingdom. Eight members of the seminar were Africans, the rest being Europeans working in Africa. The Librarian and Acting Principal of the University College of Nigeria was host to the seminar, and the Director was Mlle Yvonne Oddon, Librarian of the Musée de l'Homme, Paris. The main work of the seminar was carried out in three working groups concerned with: (i) organizing public library services on a regional or national scale; (ii) provision and use 